http://kitaibelia.unideb.hu/

ISSN 2064-4507 (Online) • ISSN 1219-9672 (Print)

(C) Department of Botany, University of Debrecen, Hungary

23 (1): 87-102.; 2018

DOI: $10.17542 /$ kit.23.87

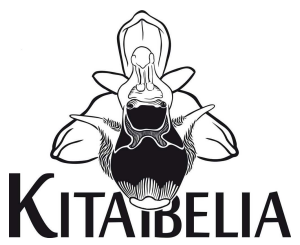

\title{
Pótlások Magyarország edényes növényfajainak elterjedési atlaszához VI.
}

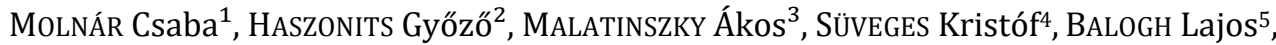 \\ NAGY Timea ${ }^{6}$, HoRvÁTH Soma ${ }^{7}$ \& HUdÁK Katalin ${ }^{8}$
}

(1) H-3728 Gömörszőlős, Kassai u. 34.; birkaporkolt@yahoo.co.uk

(2) Soproni Egyetem Növénytani és Természetvédelmi Intézet, H-9400 Sopron, Bajcsy-Zsilinszky u. 4.

(3) Szent István Egyetem MKK Természetvédelmi és Tájgazdálkodási Intézet

Természetvédelmi és Tájökológiai Tanszék, H-2103 Gödöllő, Páter K. u. 1.

(4) Debreceni Egyetem TTK Növénytani Tanszék, H-4032 Debrecen, Egyetem tér 1.

(5) Savaria Megyei Hatókörű Városi Múzeum, Természettudományi Osztály, H-9701 Szombathely, Kisfaludy Sándor u. 9.

(6) Pannon Egyetem GK Növénytudományi és Biotechnológiai Tanszék, H-8360 Keszthely, Festetics u. 7.

(7) H-3534 Miskolc, Szarka-hegy u. 46.

(8) Zöld Akció Egyesület, H-3525 Miskolc Kossuth u. 13.

\section{Contributions to the Atlas Florae Hungariae VI.}

\begin{abstract}
The current paper is the sixth one in the series aiming to contribute with new distribution data to the distribution maps published recently in Atlas Florae Hungariae. Current occurrence data of 389 vascular plant taxa from 117 flora mapping quadrates (CEU) are provided. New records are indicated from different regions of Hungary; however, most occurrences are located in the North Hungarian Mts and from the city of Szolnok and Western Hungary. Occurrence data of rare native taxa (including data of Equisetum fluviatile, Galium rivale, Gladiolus imbricatus, Hypericum maculatum, Persicaria bistorta, Potentilla inclinata, Ranunculus lingua, Rhinanthus rumelicus, Trifolium fragiferum subsp. bonannii, Viola pumila), rare or data-deficient alien taxa (e.g. Amaranthus blitum subsp. blitum, Cymbalaria muralis, Elymus elongatus, Euphorbia peplus, Heracleum sosnowskyi, Impatiens balfourii, Lepidium densiflorum, Rhus typhina, Telekia speciosa), as well as frequent but more or less underrepresented taxa (e.g. Carex otrubae, Chenopodium polyspermum, Crepis tectorum, Filipendula vulgaris, Petrorhagia prolifera, Poa palustris) are also enumerated. In case of the most common species we provided the CEU codes only.
\end{abstract}

Keywords: distribution data, flora mapping, Hungary, vascular flora

Összefoglalás - Jelen közleményünk annak a sorozatnak a hatodik része, melynek célja a Magyarország edényes növényfajainak elterjedési atlasza térképeinek kiegészítése, főként aktuális előfordulási adatokkal. Ezúttal 389 edényes taxon előfordulási adatait közöljük az ország szinte egész területéről (mintegy 117 flóratérképezési kvadrátból), de legnagyobb számban az Északi-középhegységből, Szolnok környékéről és Nyugat-Magyarországról. Az adatok között ritkább őshonos taxonok (pl. Equisetum fluviatile, Galium rivale, Gladiolus imbricatus, Hypericum maculatum, Persicaria bistorta, Potentilla inclinata, Ranunculus lingua, Rhinanthus rumelicus, Trifolium fragiferum subsp. bonannii, Viola pumila), ritka, vagy legalábbis adathiányos idegenhonos fajok (pl. Amaranthus blitum subsp. blitum, Cymbalaria muralis, Elymus elongatus, Euphorbia peplus, Heracleum sosnowskyi, Impatiens balfourii, Lepidium densiflorum, Rhus typhina, Telekia speciosa) mellett országosan elterjedt, de többé-kevésbé alulreprezentált fajok (pl. Carex otrubae, Chenopodium polyspermum, Crepis tectorum, Filipendula vulgaris, Petrorhagia prolifera, Poa palustris) esetében is közöljük az Atlasz térképeihez képest újnak bizonyuló lelőhelyeket. A legközönségesebb fajok esetében a lelőhelyek részletezése nélkül csupán KEF-kódokat adunk meg.

Kulcsszavak: edényes flóra, előfordulási adatok, flóratérképezés, Magyarország 


\section{Bevezetés}

Közleményünk a Magyarország edényes növényfajainak elterjedési atlasza (BARTHA et al. 2015) térképeinek kiegészítésére hivatott sorozat (TAKÁCS et al. 2016, MoLNÁR et al. 2016, 2017, KEVEY 2017, CSIKY et al. 2017) hatodik része. Ezúttal összesen 389 edényes taxon aktuális előfordulási adatait közöljük, köztük - a korábbi közleményekhez hasonlóan - néhány olyan taxonét is, amelyekről az Atlasz csupán csoportba összevonva közöl elterjedési adatokat (például Achillea millefolium L. s. str., Agrostis gigantea Roth, Carex praecox Schreb. subsp. intermedia (Čelak.) W. Schultze-Motel, Leucanthemum ircutianum DC., Polygonum rurivagum Jord.). Adataink 117 flóratérképezési kvadrátot egészítenek ki, amelyek elsősorban az Északi-középhegységben vannak, de sok adatot közlünk Szolnok környékéről és Nyugat-Magyarországról is (1. ábra). Összesen 604 új adattal járulunk hozzá az Atlaszhoz. Adataink szórványosak, 55 kvadráthoz csupán 1-1 adattal járulunk hozzá, 45 kvadráthoz 2-10 adattal, 14 kvadráthoz 11-30 adattal, végül 31 adattal a 7794.3-as kvadráthoz (Szegilong), 37 adattal a 8887.1-es kvadráthoz (Szolnok) és 46 adattal a 7591.1-es kvadráthoz (Rakaca) (1.ábra), jellemzően olyan területekről, ahová az utóbbi években a szerzők terepmunkája összpontosult. Az adatok egy része a flóratérképezés során a szerzők által felmért kvadrátok flóralistáját egészíti ki, a kitöltött adatlapok leadása utáni terepmunkák eredményeként. Az adatok döntően 2017-ben keletkeztek, vagy amennyiben ettől eltérő időpontban, azt minden esetben jelezzük a kvadrát sorszáma előtt.

A taxonok sorszámozása és nevezéktana KIRÁLY (2009) munkáját követi. A taxon neve után az adathoz tartozó település neve és dűlőnév, vagy részletesebb leírás következik, majd szögletes zárójelben az adat keletkezésének ideje (ha 2017-től eltér), a közép-európai flóratérképezés vonatkozó kvadrátjának azonosítója (NIKLFELD 1971), végül az adatközlők monogramja (vö. szerzők). Balogh Lajos továbbította Lendvai Zoltán (LZ, Kisunyom), Takács Béla (TB, Tömörd) és Varga László (VL, Szombathely) adatait, Süveges Kristóf Gulyás Gergellyel (GG, Debrecen) közös adataikat. A legközönségesebb fajok esetében a lelőhelyek részletezése nélkül csupán KEF-kódokat adunk meg. Egyes esetekben herbáriumi gyűjtéssel is megerősítjük az adatokat. A gyűjtött anyagot „MCs” a MTM Növénytárában (BP), „NT, SK, MCs” a Debreceni Egyetem Soó Rezső Herbáriumában (DE) és „BL” a szombathelyi Savaria Múzeum Herbáriumában (SAMU) helyezte el.

Az Enumerációban felsorolt adataink közül kiemelkednek az országosan ritka, vagy erősen adathiányos Equisetum fluviatile L. em Ehrh., Ophioglossum vulgatum L., Centaurea indurata Janka, Fritillaria meleagris L., Fumaria rostellata Knaf, Galium rivale (Sibth. et Sm.) Griseb., Gladiolus imbricatus L., Hypericum maculatum Crantz, Persicaria bistorta (L.) Samp., Potentilla inclinata Vill., Ranunculus lingua L., Rhinanthus rumelicus Velen., Trifolium fragiferum L. subsp. bonannii (C. Presl) Soják és Viola pumila Chaix lelőhelyei.

Közöljük ritka, vagy legalábbis adathiányos idegenhonos fajok és szubspontán megjelenő honos fajok (például Amaranthus blitum L. subsp. blitum, Cymbalaria muralis G. Gaertn., B. Mey. et Scherb., Elymus elongatus (Host) Runemark cv. Szarvasi-1, Euphorbia peplus L., Heracleum sosnowskyi Manden., Hippophaë rhamnoides L., Impatiens balfourii Hook., Lepidium densiflorum Schrad., Portulaca grandiflora Hook, Rhus typhina L., Telekia speciosa (Schreb.) Baumg.) adatait is.

Számos adatot közlünk továbbá útszélekről és vasúti létesítmények mellől (pl. Equisetum ramosissimum Desf., Amaranthus blitoides S.Watson, Draba nemorosa L., Microrrhinum minus (L.) Fourr., Pulicaria vulgaris Gaertn., Sagina procumbens L., Sisymbrium loeselii L.). Itt jegyezzük meg, hogy a Rumex thyrsiflorus Fingerh. Észak-Magyarországon, útszéleken és útszélek menti száraz gyepekben épp napjainkban terjed. A térségben száraz gyepekben szórványosan korábban is megfigyelhető volt, sőt, figyelembe kell vennünk, hogy a $R$. acetosa L.-val való keverése miatt az ország nagy részén jelentősen alultérképezett a faj (SCHMIDT D. ex lit.), de megfigyeléseink és az, hogy útszéleken koncentrálódnak az állományai, a gyors terjedés mellett szólnak. 
Mindezek mellett országosan elterjedt, gyakori, de az Atlaszban adathiányos taxonok előfordulásait is közöljük (például Agrostis stolonifera L., Carex otrubae Podp., Chenopodium polyspermum L., Crepis setosa Haller, C. tectorum L., Festuca valesiaca Schleich. ex Gaudin, Filipendula vulgaris Moench, Geranium robertianum L., Petrorhagia prolifera (L.) P.W. Ball \& Heywood, Poa palustris L.).

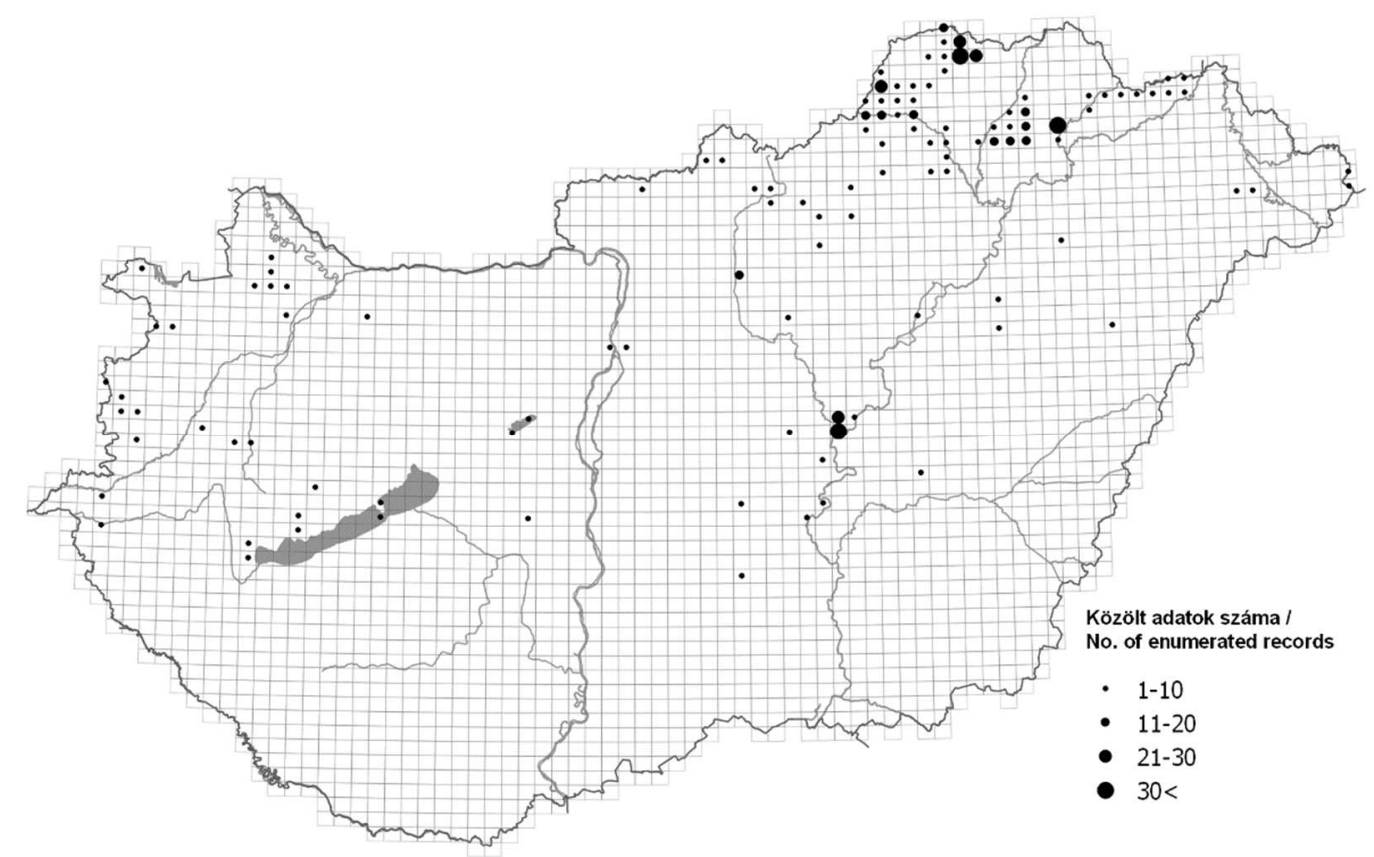

1. ábra. A közleményben összefoglalt előfordulási adatok a közép-európai flóratérképezés (KEF) hálórendszerének kvadrátjaira vetítve

Fig. 1. Distribution of localities of presented data, projecting for the quadrates of the Central European flora mapping system (CEU)

\section{Enumeráció}

12. Equisetum fluviatile L. em. Ehrh. - Bódvalenke: Kotra [7490.4, MCs]; Szalonna: Rakacavíztározó [7590.4, SK].

13. Equisetum palustre L. - Tárnokréti: tehénlegelőn tömeges [8269.4, HGy].

14. Equisetum ramosissimum Desf. - Szolnok: vasútparti kövezésben [8887.1, HGy].

17. Ophioglossum vulgatum L. - Szombathely: a Kámon és Olad közötti vízmű gyűjtőterület kaszálórétjének szélén 10-15 egyed, néhány sporofillumos is [2016, 8765.4, BL].

32. Asplenium scolopendrium L. - Bozsok: É-i határában, a Sötét-völgybe induló erdei út rézsűjében egy tő [1980/'90-es évek fordulója, kipusztult, 8664.4, TB, BL]; Szombathely: Széll Kálmán utca, Savaria Múzeum É-i fala tövében a pince szellőzőrácsában egy fiatal tő [2009, 2010, kipusztult, 8765.4, BL].

33. Asplenium ceterach L. - Gyulakeszi: Csigó-malom kőkerítésén több tucat tő [9170.2, BL].

40. Asplenium ruta-muraria L. - Hidvégardó: Szent János-kő [7491.3, MCs].

56. Dryopteris carthusiana (Vill.) H.P. Fuchs - Abaújkér: Gyűr-völgy [7793.1, MCs]; Sajónémeti: Aszó [7788.1, MCs].

61. Salvinia natans (L.) All. - Szalonna: Rakaca-víztározó [7590.2, 7590.4, SK]. 
101. Salix viminalis L. - Kisbabot: Rába parton [8470.1, HGy].

128. Quercus robur L. - Monok: Lete-erdő [7892.2, MCs].

146. Urtica urens L. - Gömörszőlős: belterület [7688.2, MCs].

151. Thesium ramosum Hayne - Rakaca: Szendi-oldal [7591.1, MCs].

157.1 Asarum europaeum L. subsp. europaeum - Tornaszentjakab: Kerek-domb [7491.3, MCs].

160. Persicaria bistorta (L.) Samp. - Szászfa: Nagy-rét és Rakaca: Szászfai-sarok [7591.1,

2014-2017, HS, HK, MCs]; Szászfa: Janka-patak völgye [7591.2, 2014-2017, HS, HK, MCs].

165. Persicaria dubia (Stein) Fourr. - [7794.3, MCs]; [8887.1, HGy].

171. Polygonum rurivagum Jord. - Erdőbénye: Petrás-oldal, vadtaposta, nyílt, gyomos lejtősztyeppréten [herb, 7794.3, MCs].

178. Fallopia dumetorum (L.) Holub - Monok: Monoki-erdő [7892.2, MCs].

185. Rumex acetosella L. - Lácacséke: Szilvás-homok [7697.2, MCs]; Putnok: Külső bányatelep, szénbányászati meddőhányón [7788.2, MCs].

187. Rumex acetosa L. - [7591.2, MCs].

188. Rumex thyrsiflorus Fingerh. - Bátonyterenye: belterület, útszél [7985.3, 8085.1, NT, MCs]; Gömörszőlős: Egerdő-tető és Karu fészke [7688.2, MCs]; Dédestapolcsány: Mályinkai elágazás buszmegálló [7888.2, MCs]; Karcsa [7696.4, MCs] és Karos: belterületi útszélek [7696.3, MCs]; Kazincbarcika: belterületi gyepekben és útszéleken [7789.2, MCs]; Kisrozvágy, Nagyrozvágy és Semjén: útszélek [7697.4, MCs]; Lácacséke: Szilvás-homok és belterületi útszélek [7697.2, MCs]; Mátraballa [8086.1, NT, MCs] és Mátraderecske: belterületi útszélek [8086.4, NT, MCs]; Pácin: belterületi útszélek [7697.3, MCs]; Perkupa: Jósvafő-Aggtelek vasútállomás [7590.1, MCs]; Putnok: Külső bányatelek és Sajóvelezd: útszélek [7788.2, MCs]; Sajóecseg: Sajóbábonyi elágazás buszmegálló és a faluba vezető műút mezsgyéje [7890.2, MCs]; Sajónémeti: Rátos-tető, belterületi útszélek és vasútállomás [7788.1, MCs]; Serényfalva: Héti elágazás és bánrévi út mente [7688.3, MCs]; Sóstófalva: Sóstófalvi elágazás buszmegálló [7891.2, MCs]; Tornanádaska: vasútállomás [7490.2, MCs]; Vadna: Sziget, kavicsbányató töltése [7789.1, MCs]; Vajdácska: belterületi gyepek, útszélek [7695.4, MCs]; Zemplénagárd: belterületi útszélek és a temető melletti domb [7698.1, MCs]; Zemplénagárd: Aszpa-dúlő [7698.3, MCs].

193. Rumex palustris Sm. - Gömörszőlős: belterületi udvaron [herb, 7688.2, MCs].

198. Rumex conglomeratus Murray - Putnok: Külső bányatelep, szénbányászati meddőhányón [7788.2, MCs].

207. Polycnemum arvense L. - Erdőbénye: Petrás-oldal [7794.3, MCs].

217. Chenopodium glaucum L. - Gömörszőlős: belterületi udvarokon [herb, 7688.2, MCs]; Hortobágy-Szásztelek: Halas-fenék [8492.3, SK].

220. Chenopodium vulvaria L. - Fehérgyarmat: a Mol-kút pakolójának gyomtársulásában [8001.1, SK, GG]; Gárdony: belterület [8777.4, SK]; Tihany: belterületen [9073.3, SK]; Tószeg: temető [8986.2, SK].

221. Chenopodium polyspermum L. - [7795.1, 7892.1, MCs].

224. Chenopodium urbicum L. - Hortobágy-Szásztelek: Halas-fenék [8492.3, SK].

255. Salsola kali L. s. str. - Putnok: Külső bányatelep, szénbányászati meddőhányón [herb, 7788.2, MCs].

264.1 Amaranthus blitum L. subsp. blitum - Gömörszőlős: belterület [herb, 7688.2, MCs].

266. Amaranthus blitoides S.Watson - Budapest: Baross tér, fal tövében [herb, 8580.1, MCs]; Kazincbarcika: Egressy Béni út mentén, csatorna repedésében [herb, 2016, 7789.4, MCs]; Sarud: Pap-tag [8489.2, SK].

269. Amaranthus albus L. - Putnok: Külső bányatelep, szénbányászati meddőhányón [herb, 7788.2, MCs].

273. Phytolacca americana L. - Gérce: a Farkas-erdőben helyenként tömeges [2000-es évek első fele, 8867.2, BL]; Szigliget: az arborétumban és környékén többhelyütt [2001, 9170.4, BL]. 
275. Portulaca grandiflora Hook. - Szombathely: Kisfaludy Sándor utca, aszfaltozott út és járda közötti szegélyhasadékban, P. oleracea társaságában [2012, 8765.4, BL].

276. Portulaca oleracea L. - [7789.1, MCs].

281. Arenaria serpyllifolia L. - [8887.1, HGy].

297. Stellaria graminea L. - Felsőkelecsény: Felső-rét [7689.2, MCs].

299. Holosteum umbellatum L. - [7793.3, MCs].

301. Cerastium glomeratum Thuill. - Abaújkér: Gyűr-tető [7793.1, MCs].

303. Cerastium brachypetalum Desp. s. str. - Erdőbénye: Petrás-oldal [7794.3, MCs].

306. Cerastium pumilum Curtis - Tállya: Csátó [7793.3, MCs].

315. Sagina procumbens L. - Abaújszántó: piactér kútja körüli díszkövezet réseiben [herb, 7793.1, MCs]; Dédestapolcsány: italbolt buszmegálló, díszkövezet réseiben [7888.2, MCs]; Kisbabot: kőrepedések, járdaszegélyek [8470.1, HGy]; Miskolc: Széchenyi utca és környéke diszkövezetében [7890.4, MCs]; Nagyvisnyó: Bánkúti turistaház udvarán díszkövezet réseiben és gyepben [7988.2, MCs]; Putnok: Gömör Áruházzal szemben, díszkövezet réseiben [7788.2, MCs]; Sárospatak: vasútállomás [7695.3, MCs]; Szolnok: járdaszegélyeken városszerte [8887.1, HGy].

323. Scleranthus annuus L. - Erdőbénye: Petrás-oldal [7794.3, MCs].

334. Lychnis flos-cuculi L. - Rakaca: Szendi-oldal és Szászfa: Nagy-rét [7591.1, MCs]; Szászfa: Janka-patak völgye [7591.2, MCs].

336. Lychnis viscaria L. - Abaújkér: Gyűr-tető [7793.1, MCs].

339.2 Silene otites (L.) Wibel subsp. hungarica Wrigley - Sajónémeti: Vár-hegy [7788.1, MCs]. 350. Silene viscosa (L.) Pers. - Megyaszó: Csorgó-legelő [7892.1, MCs].

352. Silene noctiflora L. - Alsódobsza: Kút-völgy, beszántott forráskifolyónál [7892.1, MCs]; Gömörszőlős: Csató-bérc, legelt parlagon és belterületi udvarokon [7688.2, MCs].

360. Gypsophila paniculata L. - Lácacséke: Szilvás-homok [7697.2, MCs].

364. Petrorhagia prolifera (L.) P.W. Ball \& Heywood - Zemplénagárd: a temető melletti dombon és gátoldalban [7698.1, MCs].

373. Dianthus pontederae A. Kern. s. str. - Lácacséke: Szilvás-homok [7697.2, MCs]

381. Nymphaea alba L. - Szombathely: Árpád út, Vasi Skanzen, a vízimalom mesterséges holtága végöblében egy dolgozó 2010. évi telepítése nyomán napjainkig állandósult állomány [2012] és Szombathely: a Csónakázó-tó ÉK-i, majd ÉNy-i sarkában felbukkanó, kisebb állományok [2009, 2017, 8765.4, BL].

382. Nuphar lutea (L.) Sm. - Szombathely: Horgász-tó, a Vasi Múzeumfalu malomágában napjainkig állandósult állomány [2010 k., 8765.4, BL].

397. Caltha palustris L. - Monok: Hosszú-völgy, Oláh-völgy és Zsellér-part [7792.4, MCs].

404. Consolida orientalis (J. Gay) Schrödinger - Szolnok: Száraz gyepekben, vasúti hídtól Éra [8887.1, HGy].

418. Clematis integrifolia L. - Szolnok: Zagyva-ártér üde rétjein, folyómenti réteken, töltésoldalakban magas tőszámmal [8787.3, HGy].

427. Adonis aestivalis L. - Sajósenye: Boldvai-part alatt, szántó szélén [7790.4, MCs].

435. Ranunculus ficaria $\mathrm{L}$. - [7892.2, MCs].

436. Ranunculus pedatus Waldst. et Kit. - Monok: Hosszú-völgy és Oláh-völgy [herb, 7792.4, MCs].

437. Ranunculus illyricus L. - Abaújalpár: Bánya-hegy, nagyobb összefüggő foltokban, hozzávetőlegesen 20-30 m² összkiterjedésben [7693.3, MCs].

443. Ranunculus lingua L. - Fehértó: a tó rekettyefüzes szegélyében, nedves tisztáson [8370.1, HGy].

446. Ranunculus sardous Crantz - Szolnok: Zagyva hullámterében [8887.1, 8787.3, HGy];

Szuhogy: Verő-oldal, szántó szélén [herb, 7690.1, MCs].

447. Ranunculus repens L. - [7591.2, MCs].

450. Ranunculus auricomus agg. - Szászfa: Janka-patak völgye [7591.1, 7591.2, MCs]. 
451. Ranunculus polyanthemos L. s. str. - Felsőkelecsény: Felső-rét [7689.2, MCs]; Szászfa: Janka-patak völgye [7591.1, 7591.2, MCs].

454. Ranunculus lanuginosus L. - Sajóvelezd: Ilona-forrás [7788.2, MCs].

466. Thalictrum lucidum L. - Szegilong: Örvény [7794.3, MCs]; Tornanádaska: Töltés felett [7490.2, MCs].

480.1 Papaver dubium L. subsp. albiflorum (Boiss.) Dostál - Kazincbarcika: Kb. alsó vasúti megállóhely [7789.2, MCs]; Sajóecseg: vasútállomás [7890.2, MCs].

490. Fumaria rostellata Knaf - Abaújszántó: Gyür-tető oldala, búzavetésben [herb, 7793.1, MCs].

492. Fumaria schleicheri Soy.-Will. - Serényfalva: Pogonyipuszta vasúti megállóhely [7788.1,

MCs]; Tornanádaska: vasúti sínek mentén [7490.2, MCs].

496. Sisymbrium strictissimum L. - Sajóvelezd: Vár-hegy erdeje [7788.2, MCs].

500. Sisymbrium loeselii L. - Kazincbarcika: Kb. alsó vasúti megállóhely [7789.2, MCs].

503. Arabidopsis thaliana (L.) Heynh. - [7794.3, 7990.2, 9084.3, MCs].

508. Erysimum cheiranthoides L. - Putnok: Külső bányatelep, szénbányászati meddőhányón [herb, 7788.2, MCs].

518. Hesperis sylvestris Crantz - Kelemér: Kijáró, ugaron 2 tő [herb, 7688.2, MCs].

527. Rapistrum perenne (L.) All. - Monok: Nagy-tábla és Laposok közötti út mezsgyéje [7792.4, MCs].

542.1 Cardamine pratensis L. subsp. matthioli (Moretti) Nyman - Tállya: Csátó [7793.3, MCs].

554. Lunaria annua L. subsp. annua - Velem: a falutól DNy-ra, a Bozsoki-patak mentén, erdőben [2000-es évek, 8664.4, LZ].

556. Alyssum alyssoides L. - Hidvégardó: Szent János-kő [7491.3, MCs]; Meszes: Jóna-hegy

[7590.2, 7590.4, MCs]; Rakaca: a belterülettől Ny-ra, útszéli sziklaletörésen [7591.1, MCs].

558. Alyssum montanum L. - Abaújkér: Gyür-tető [herb, 7793.1, MCs].

560. Berteroa incana (L.) DC. - Szolnok: Tallinn városrész széle, útpartok [8887.1, HGy].

567. Rorippa sylvestris (L.) Besser - [7688.2, MCs és 7888.2, MCs]; [8887.1, HGy].

569. Draba nemorosa L. - Putnok: vasútállomás [herb, 7788.2, MCs].

571. Erophila verna (L.) Chevall. - [7792.4, 7892.2, MCs].

583. Thlaspi perfoliatum L. $-[7793.3,9084.3, \mathrm{MCs}]$.

600. Lepidium ruderale L. - [8887.1, HGy].

601. Lepidium densiflorum Schrad. - Kazincbarcika: Kb. alsó vasúti megállóhely [7789.2,

MCs]; Tornanádaska: vasútállomás és a sínek mentén [7490.2, MCs]; Vadna: vasútállomás [7789.1, MCs].

668. Filipendula vulgaris Moench - Szászfa: Janka-patak völgye [7591.2, 2014-2017, HS, HK, MCs]. 685. Rosa gallica L. - Abaújalpár: Bánya-hegy [7693.3, MCs].

716. Waldsteinia geoides Willd. - Monok: Pap erdeje, Lány-kő [7893.1, MCs].

727. Potentilla inclinata Vill. - Hidvégardó: Szent János-kő [7491.3, MCs].

725. Potentilla reptans $\mathrm{L}$ - [7794.3, MCs].

818. Padus serotina (Ehrh.) Borkh. - Szolnok: NEFAG Zrt. melletti erdőtömbben [8787.3, HGy].

821. Cerasus fruticosa (Pall.) Woronow - Meszes: Jóna-hegy [7590.2, 7590.4, MCs]; Rakaca: a belterülettől Ny-ra, útszéli sziklaletörésen [7591.1, MCs].

822.1 Cerasus vulgaris Mill. subsp. acida (Dumort.) Dostál - Kissomlyó: a kőfejtőben gyakori [2011, 8868.4, BL].

861. Colutea arborescens L. - Sajónémeti: Vár-hegy [7788.1, MCs].

870. Astragalus cicer L. - Zemplénagárd: gátoldal [7698.1, MCs].

887. Vicia hirsuta (L.) S.F. Gray - [7591.1, 7591.2, 7688.2, MCs].

888. Vicia tetrasperma (L.) Schreb. - [7693.3, 7698.3, MCs].

891. Vicia pisiformis L. - Zemplénagárd: Aszpa-dűlő [7698.3, MCs].

900. Vicia lathyroides L. - Abaújalpár: Bánya-hegy [7693.3, MCs]. 
901.2 Vicia pannonica subsp. striata (M. Bieb.) Nyman. - Szolnok: Erdészettől É-ra fekvő száraz gyep és a töltésláb találkozásánál [8787.3, HGy].

903. Vicia grandiflora Scop. - [7698.3, 8989.4, MCs].

905. Vicia sepium L. - Rakacaszend: Rakaca-menti kaszálókon [7591.1, MCs].

908.1 Vicia angustifolia L. subsp. angustifolia - [7689.2, MCs].

911. Lathyrus nissolia L. - Gömörszőlős: Egerdő-tető, parlagon [7688.2, MCs]; Olaszliszka: Meszesmajor [7794.3, MCs]; Tornaszentjakab: Kerek-domb alja [7491.3, MCs].

912. Lathyrus pratensis L. - Szászfa: Janka-patak völgye [7591.2, MCs]; Tállya: Csátó [7793.3, MCs].

916. Lathyrus hirsutus L. - Olaszliszka: Meszesmajor [7794.3, MCs]; Szuhogy: Verő-oldal, szántó szélén [7690.1, MCs].

921. Lathyrus sylvestris L. - Garbolc: a Túr folyó hullámterében, függöny társulásban [8003.1, $\mathrm{SK}, \mathrm{GG}]$.

922. Lathyrus latifolius L. - Sóstófalva: Bárkán, frissen beszántott legelőn [7891.2, 7892.1, MCs].

929. Lathyrus vernus (L.) Bernh. - Tornaszentjakab: Kerek-domb [7491.3, MCs].

935. Ononis arvensis L. - Tornanádaska: Töltés felett [7490.2, MCs].

937. Melilotus albus Desr. - Vadna: Sziget [7789.1, MCs].

938. Melilotus dentatus (Waldst. et Kit.) Pers. - Gárdony-Dinnyés: a tóparti kerékpárút mellett [8877.1, SK]; Sukoró: tóparton a Lapos-dúlő és a Kis-dúlő között [8777.4, SK].

945. Medicago sativa L. - [7591.1, MCs].

953. Medicago minima (L.) L. - Hidvégardó: Szent János-kő [herb, 7491.3, MCs].

958. Trifolium hybridum L. - [7794.3, MCs].

961. Trifolium aureum Pollich - Hidvégardó: Szent János-kő [herb, 7491.3, MCs].

963. Trifolium campestre Schreb. - [7591.1, MCs].

967. Trifolium montanum L. - Rakaca: Szendi-oldal [7591.1, MCs].

968. Trifolium retusum L. - Szolnok: Erdészettől É-ra fekvő száraz gyepben [8787.3, HGy].

970. Trifolium fragiferum L. - Szolnok: taposott útpartok, száraz gyepek [8787.3, HGy].

970.2 Trifolium fragiferum L. subsp. bonannii (C. Presl) Soják - Olaszliszka: Meszesmajor [herb, 7794.3, MCs].

973. Trifolium alpestre L. - Monok: Oláh-völgy [7792.4, MCs]; Rakaca: Szendi-oldal [7591.1, MCs].

976. Trifolium pannonicum Jacq. - Tornaszentjakab: Kerek-domb alja [7491.3, MCs].

980. Trifolium striatum L. - Abony: Abony centrumtól 3 km-re, Ny-ra, 40-es út menti száraz gyepben [8885.2, HGy].

983. Trifolium arvense L. - [7591.1, MCs].

1005. Oxalis dillenii Jacq. - Sajósenye: Boldvai-part alatt, szántó szélén [7790.4, MCs]; Zemplénagárd: Aszpa-dűlő [7698.3, MCs].

1007. Geranium robertianum L. - [7893.1, MCs].

1009. Geranium sanguineum L. - Rakaca: a belterülettől Ny-ra, útszéli sziklaletörésen [7591.1, MCs].

1014. Geranium columbinum L. - Erdőbénye: Petrás-oldal [7794.3, MCs].

1021. Geranium pusillum Burm. f. - [7490.2, 7688.2, MCs].

1034. Linum austriacum L. - Felsődobsza: Hernád-magaspart [7792.3, MCs].

1042. Euphorbia maculata L. - Abaújszántó: piactér kútja körüli díszkövezet réseiben [7793.1, MCs]; Debrecen: Babits Mihály u. [8495.4, SK]; Domoszló: a katolikus templommal szemben lévő telken [8186.4, SK]; Mátészalka: Jármi u., a Suzuki szalon és a Mustafa Gyros közötti parkoló térkövei között [8099.2, SK, GG]; Miskolc: a repülőtér melletti bevásárlóközpontok díszkövezetében [7890.4, MCs].

1045. Euphorbia platyphyllos L. - [8787.3, HGy].

1058. Euphorbia salicifolia Host - Abaújszántó: Mező-fenék [7792.2, MCs].

1061. Euphorbia esula L. - Szolnok: Zagyva mente, partközelben, vasúti hídtól É-ra [8887.1, HGy]. 
Kitaibelia 23 (1): 87-102.

1062. Euphorbia virgata Waldst. et Kit. - Sóstófalva: Bárkán, frissen beszántott legelőn [7892.1, MCs].

1063. Euphorbia lucida Waldst. et Kit. - Szolnok: Tisza árterében, kaszált gyomos réten. A rét 20\%-a nem volt lekaszálva, itt a Cirsium arvense az uralkodó [8887.1, HGy].

1064. Euphorbia peplus L. - Gömörszőlős: belterület, udvarokban [herb, 7688.2, MCs].

1070. Dictamnus albus L. - Rakaca: a belterülettől Ny-ra, útszéli sziklaletörésen, néhány tő [7591.1, MCs].

1076. Polygala comosa Schkuhr - Abaújalpár: Bánya-hegy [7693.3, MCs]; Monok: Hosszúvölgy [7792.4, MCs].

1080. Rhus typhina L. - Kemenespálfa: K-re, út mentén hosszú, kiterjedt sarjtelep [2011, 8869.3, BL]; Lövő: DNy-i határában terjedő sarjtelepek [2010, 8466.4, BL]; Pannonhalma: az arborétumban, nagy sarjtelepekben elvadulva [2016, 8472.2, BL]; Szántód: Szántódpuszta Ny-i végén, a műút és a nádas között kb. 30 m átmérőjű sarjtelep [2010, 9173.1, BL].

1089. Impatiens noli-tangere L. - Tornaszentjakab: Nagy-erdő [7491.3, MCs].

1090. Impatiens parviflora DC. - Hidvégardó: Sas-patak menti bozótban [7490.4, MCs]; Sajónémeti: Aszó, bükkös alatt óriási tömegben [7788.1, MCs].

1091. Impatiens glandulifera Royle - Miskolc-Bükkszentlászló: Galya-tető nyugati pereme, patakparton [herb, 7990.1, NT, SK, MCs].

1092. Impatiens balfourii Hook. - Miskolc-Bükkszentlászló: Galya-tető nyugati pereme, patakparton [herb, 7990.1, NT, SK, MCs].

1117. Malva sylvestris L. - [8887.1, HGy].

1121. Lavatera thuringiaca L. - [7591.1, MCs].

1135. Thymelaea passerina (L.) Coss. et Germ. - Sajókápolna: temető [7890.1, SK].

1136. Hippophaë rhamnoides L. - Fertőrákos: Meggyesi út mellett lévő felhagyott kőfejtő cserjés szegélyében, idős és fiatal egyedek egyaránt megtalálhatók. Valószínúleg a környékbeli kertekből történt a kivadulás [8265.4, HGy].

1143. Hypericum maculatum Crantz s. str. - Tornaszentjakab: Kerek-domb alja, sovány legelőn [herb, 7491.3, MCs].

1151.2 Viola arvensis Murray subsp. megalantha Nauenb. - Kazincbarcika: Kb. alsó vasúti megállóhely [herb, 7789.2, MCs].

1152. Viola kitaibeliana Roem. et Schult. - Kecskemét: vasútállomás [9084.3, MCs].

1153.2 Viola alba Besser subsp. scotophylla (Jord.) Nyman - Megyaszó: Hosszú-hegy [herb, 7892.2, MCs]; Monok: Ingvár és Monoki-erdő [7893.1, MCs].

1156. Viola mirabilis L. - Sajónémeti: Vár-hegy [7788.1, MCs].

1163.1 Viola elatior Fr. subsp. elatior - Vajdácska: Legelő [7696.3, MCs].

1164.2 Viola canina L. subsp. montana (L.) Hartm. - Abaújkér: Gyür-tető [herb, 7793.1, MCs].

1165. Viola pumila Chaix - Szászfa: Janka-patak völgye [herb, 7591.1, 7591.2, MCs].

1182. Bryonia alba L. - [7795.1, MCs].

1194. Peplis portula L. - Vajdácska: Diófás-dűlő, földúton, keréknyomban [7695.4, MCs].

1195. Lythrum virgatum L. - Szegilong: Örvény [7794.3, MCs].

1196. Lythrum salicaria $\mathrm{L}-[7591.2, \mathrm{MCs}]$.

1197. Lythrum hyssopifolia L. - Alsódobsza: Kút-völgy, beszántott forráskifolyónál [7892.1, MCs].

1217. Chamaenerion angustifolium (L.) Scop. - Budapest: Keleti pályaudvar, 3-as vágány ütközője mellett [8580.2, MCs].

1219. Epilobium hirsutum L. - Szolnok: Zagyva mente, csatornapartok [8887.1, 8787.3, HGy].

1244. Eryngium planum L. - Szolnok: Zagyvatöltés oldalában, erdészet mögötti területen [8787.3, HGy].

1266. Libanotis pyrenaica (L.) Bourg. - Abaújszántó: Szerencs-patak mente [7793.3, MCs].

1271. Seseli varium Trevir. - Felsődobsza: Hernád-magaspart [7792.3, MCs]. 
MoLNÁR et al. (2018): Pótlások Magyarország edényes növényfajainak elterjedési atlaszához VI.

1273. Oenanthe aquatica (L.) Poir. - Szolnok: Ispán krt. közúti híd tövében, Zagyvaparton, több helyen is [8887.1, HGy].

1287. Bupleurum tenuissimum L. - Szolnok: Tallinn városrész, földút mellett, taposott szegélynövényzetben [8887.1, HGy].

1320. Tordylium maximum L. - Olaszliszka: Meszesmajor [7794.3, MCs].

1324. Torilis arvensis (Huds.) Link - [8787.3, HGy].

1351. Androsace elongata L. - Meszes: Jóna-hegy [7590.2, 7590.4, MCs].

1384. Gentiana cruciata L. - Gömörszőlős: Mocsályák és Kolyota között [7688.2, MCs]; Rakaca: Lucernás és Szendi-oldal [7591.1, MCs].

1393. Vinca minor L. - Sajónémeti: Rátos-oldal [7788.1, MCs].

1395. Asclepias syriaca L. - Abaújszántó: Mező-fenék [7792.2, MCs]; Alsódobsza: Cserjedomb [7892.1, MCs]; Gencsapáti: Gencsi-erdő, dűlőút menti tisztáson kb. $10 \mathrm{~m}^{2}$-es foltban [1990 k., 8765.1, BL]; Rakacaszend: Vágott-erdő alja, szántók között [7591.1, MCs]; Sajónémeti: vasútállomás [7788.1, MCs].

1398. Calystegia sepium (L.) R. Br. - [8787.3, 8887.1, HGy].

1399. Convolvulus arvensis L. - [8787.3, HGy].

1411. Heliotropium supinum L. - Jászdózsa: Új-kút-dűlő [2016, 8485.2, SK].

1414. Buglossoides arvensis (L.) I.M. Johnstone - [7790.4, MCs].

1426. Pulmonaria mollissima A. Kern. - Szerencs-Ond: Fekete-hegy [7893.1, MCs].

1440. Asperugo procumbens L. - Felsődobsza: Hernád-magaspart [7792.3, MCs].

1447. Myosotis stricta Link - [7892.2, MCs].

1450. Myosotis arvensis (L.) Hill - [7590.2, 7591.1, MCs].

1451. Myosotis ramosissima Rochel - [7793.1, 7794.3, MCs].

1455. Lappula squarrosa (Retz.) Dumort. - Szolnok: mezőgazdasági művelésbe vett gyomos területek [8787.3, HGy]; Taliándörögd: a Klastromtól D-re, mákföldön [2014, 9071.1, BL].

1460. Cynoglossum hungaricum Simonk. - Hidvégardó: Szent János-kő [herb, 7491.3, MCs]; Lácacséke: Szilvás-homok [7697.2, MCs].

1470. Ajuga chamaepitys (L.) Schreb. - Gömörszőlős: Csató-bérc, földút szélén [7688.2, MCs]

1475. Teucrium montanum L. - Sajónémeti: Aszó-tető [7788.1, MCs].

1479. Scutellaria hastifolia L. - Rakaca: Szendi-oldal és Szászfa: Janka-patak völgye [7591.1, MCs]; Szolnok: hullámtéri üde gyepben [8787.3, HGy].

1480. Scutellaria galericulata L. - Tornaszentjakab: Sas-pataki földek [7491.3, MCs].

1487.2 Melittis melissophyllum L. subsp. carpatica (Klokov) P.W. Ball - Tornaszentjakab: Kerek-domb [7491.3, MCs].

1491. Galeopsis angustifolia (Ehrh.) Hoffm. - Lébény: Ottó-majori száraz gyepben [8269.2, HGy].

1505. Leonurus marrubiastrum L. - Hortobágy-Szásztelek: Halas-fenék [8492.3, SK]; Szolnok: ártereken, csatornapartokon, nedves réteken [8887.1, HGy].

1511. Stachys palustris L. - Szolnok: Zagyva parton magassásos növényzetben [8887.1, HGy]; Tállya: Csátó [7793.3, MCs].

1516. Nepeta pannonica L. - Sárbogárd: a Bolondvár környékén, löszgyepben [2009, 9177.2, BL].

1518. Glechoma hederacea L. - [7591.2, MCs].

1522. Prunella laciniata L. - Hidvégardó: Szent János-kő [7491.3, MCs].

1524. Prunella grandiflora (L.) Scholler - Abaújalpár: Bánya-hegy [7693.3, MCs].

1527. Acinos arvensis (Lam.) Dandy - Rakaca: a belterülettől Ny-ra, útszéli sziklaletörésen [7591.1, MCs].

1530. Clinopodium vulgare L. - Zemplénagárd: Aszpa-dűlő [7698.3, MCs].

1538.1 Thymus glabrescens Willd. s. str. - Legyesbénye: Majos és Monok: Pipiske [7892.2, MCs]. 1540.2 Thymus praecox Opiz subsp. badensis (Heinr. Braun) Ronniger - Hidvégardó: Szent János-kő [7491.3, MCs].

1541. Lycopus europaeus L. - [7794.3, MCs]. 
1542. Lycopus exaltatus L. f. - Szolnok: árokpartok, félszáraz gyepek [8787.3, 8887.1, HGy].

1543. Mentha pulegium L. - [8787.3, 8887.1, HGy].

1572. Physalis alkekengi L. - Gömörszőlős: belterületi, zárt lombkoronaszintű gyümölcsösben [7688.2, MCs].

1596. Verbascum blattaria L. - Gömörszőlős: belterület [7688.2, MCs]; Szolnok: félszáraz gyepekben [8887.1, HGy].

1597. Verbascum chaixii Vill. subsp. austriacum (Schott) Hayek - Lácacséke: Szilvás-homok [7697.2, MCs]; Sóstófalva: Bárkán, frissen beszántott legelőn [7892.1, MCs].

1608. Scrophularia nodosa L. - Tiszakécske: Hosszúföld dűlő és a Tisza folyó között, ártéri erdő mesterséges nyiladékában [9086.4, SK].

1612. Microrrhinum minus (L.) Fourr. - Bodrogolaszi: vasútállomás [7795.1, MCs]; Hidvégardó: Szent János-kő [7491.3, MCs]; Sajóecseg: vasútállomás [herb, 7890.2, MCs].

1618. Cymbalaria muralis G. Gaertn., B. Mey. et Scherb. - Miskolc: belváros, Szinva-part [7890.4, MCs].

1619. Kickxia spuria (L.) Dumort. - Gömörszőlős: Csató-bérc, útszéleken [7688.2, MCs]; Tiszaug: a falutól É-ra, mentett oldali parlagon [9186.1, SK].

1620. Kickxia elatine (L.) Dumort. - Szolnok: Kaán Károly utca, árokszegélyben, száraz rétek mély gödreiben [8887.1, HGy]; Tiszaug: a falutól É-ra, mentett oldali parlagon [9186.1, SK].

1625. Pseudolysimachion longifolium (L.) Opiz - Csorna: 86-os főút mente, Csorna és Csatárimajor között, fehérnyáras foltban [8369.1, HGy]; Gömörszőlős: Karu fészke, völgyalji nádasban [7688.2, MCs].

1635. Veronica anagallis-aquatica L. - Alsódobsza: Kút-völgy, beszántott forráskifolyónál [7892.1, MCs].

1636. Veronica prostrata L. - [7491.3, 7892.2, MCs].

1639. Veronica teucrium L. - Rakaca: Szendi-oldal [7591.1, MCs].

1640. Veronica vindobonensis (M.A. Fisch.) M.A. Fisch. - Felsődobsza: Hernád-magaspart [7792.3, MCs].

1644. Veronica triphyllos L. - Abaújkér: Gyűr-völgy [7793.1, MCs]; Monok: Pipiske [herb, 7892.2, MCs].

1647. Veronica serpyllifolia L. - Felsőkelecsény: Csörgő-patak mente a Felső-réttel szemben [herb, 7689.2, MCs]; Szalonna: Horgász-part [7590.2, MCs].

1648. Veronica arvensis L. - [7590.2, 7591.1, 7591.2, 7793.3, MCs].

1654. Veronica sublobata M.A. Fisch. - Megyaszó: Hosszú-hegy és Monok: Ingvár, Hosszúhegy, Halom alja, Kaptár-hegy és Monoki-erdő [7892.2, és 7893.1, MCs].

1658. Veronica polita Fr. - [7793.3, 7892.2, MCs].

1660. Melampyrum cristatum L. - Abaújalpár: Bónis-hegy [7793.1, MCs].

1661. Melampyrum arvense L. - Rakaca: Szendi-oldal [7591.1, MCs]; Sajókaza: Szár-hegy [7789.2, 2009, MÁ].

1668. Euphrasia stricta Wolf - Abaújalpár: Bánya-hegy [7693.3, MCs].

1673. Rhinanthus minor L. - Szászfa: Janka-patak völgye [7591.1, 7591.2, MCs].

1674.1 Rhinanthus serotinus (Schönh.) Oborný subsp. serotinus - Felsőkelecsény: Felső-rét [7689.2, MCs]; Kelemér: Szilas alja [7688.4, MCs]; Megyaszó: Csorgó-legelő [7892.1, MCs].

1677. Rhinanthus rumelicus Velen. - Szuhogy: Csátés [herb, 7690.1, MCs].

1723. Galium boreale L. - Szászfa: Janka-patak völgye [7591.2, 2014-2017, HS, HK, MCs]; Szegilong: Örvény [7794.3, MCs].

1725. Galium rivale (Sibth. et Sm.) Griseb. - Mónosbél: az Eger-patak völgyében, magassásosban [7987.4, NT, SK].

1729. Galium palustre L. - [7490.4, MCs].

1726. Galium odoratum (L.) Scop. - Ózd-Sajóvárkony: Ladány, bükkösben és gyertyános-tölgyesben [7788.3, NT, MCs]. 
MoLNÁR et al. (2018): Pótlások Magyarország edényes növényfajainak elterjedési atlaszához VI.

1744. Galium lucidum All. - Sajókaza: Szár-hegy [7789.2, 2008, MÁ].

1747. Cruciata pedemontana (Bellardi) Ehrend. - Abony: 40-es út melletti száraz gyepben tömegesen [8885.2, HGy]; Erdőbénye: Petrás-oldal [7794.3, MCs].

1751. Plantago indica L. - Besenyszög: Kovácsi-lejáró, sóderrel leszórt pionír felszínen [8787.4, SK].

1753. Plantago tenuiflora Waldst. et Kit. - Hajdúnánás: Belső-legelő-dűlő [8194.3, SK].

1765. Viburnum lantana L. - Hatvan: Kisgombosi fás legelő [8284.3, 2010, MÁ].

1777. Valerianella dentata (L.) Pollich - Erdőbénye: Petrás-oldal [7794.3, MCs].

1784. Cephalaria transsylvanica (L.) Schrad. - Szolnok: Száraz gyepekben, bolygatott területeken, vonalas létesítmények mentén [8887.1, HGy].

1787. Dipsacus fullonum L. - Szolnok: csatornapartok, Zagyva hullámtere, félszáraz gyepek [8787.3, 8887.1, HGy].

1789. Succisella inflexa (Kluk.) Beck - Botpalád: a Palád-Csécsei csatorna jobb partján [7903.3, SK].

1801. Campanula bononiensis L. - Érsekvadkert: Göröc [7981.3, 2011, MÁ]; Sajókaza: Szárhegy [7789.2, 2008, MÁ].

1805. Campanula persicifolia L. - Alsószuha: Bakóc-völgy [7689.1, 2008, MÁ].

1807. Campanula patula L. - Szászfa: Janka-patak völgye [7591.1, 7591.2, MCs].

1821. Solidago virgaurea L. - Gömörszőlős: Szőlő-hegy [7688.2, 2006, MÁ] és Gömörszőlős: félszáraz gyepekben sokfelé [7688.2, MCs].

1824. Solidago canadensis L. - Hatvan: Kisgombosi fás legelő [8284.3, 2010, MÁ].

1847. Gnaphalium uliginosum L. - Hortobágy-Szásztelek: Halas-fenék [8492.3, SK].

1851. Inula helenium L. - Őriszentpéter: Alszer, az Ivánc felé tartó utca K-i oldalán, elhagyott épület körül, szórványosan [1990-es évek első fele, 9164.4, BL].

1852. Inula conyza DC. - Gömörszőlős: Ivánka-tető [7688.2, MCs].

1860. Pulicaria vulgaris Gaertn. - Szolnok: Tallinn, vasúti szervízlépcső aljánál, száraz bolygatott gyepben [8887.1, HGy].

1865. Telekia speciosa (Schreb.) Baumg. - Szombathely: a Csónakázó-tó szigetének magaskórós szélében néhány virágzó tő [2009] és Árpád út, Vasi Skanzen, a vízimalom mesterséges holtága végöblének parti magaskórósában szubspontán, virágzó állomány [2013, 8765.4, BL].

1867. Bidens tripartita L. - Alsószuha: Bakóc-völgy [7689.1, 2008, MÁ].

1868. Bidens frondosa L. - Hortobágy: Halastó [8392.3, SK]; Hortobágy-Szásztelek: Halas-fenék [8492.3, SK]; Szolnok: Zagyva mentén, partközelben, helyenként nagyobb foltokban [8887.1, HGy].

1869. Rudbeckia laciniata L. - Kisbabot: Rába-híd Kisbabot felőli oldalának szegélyében [8470.1, HGy].

1875. Iva xanthiifolia Nutt. - Debrecen: Vénkert [8495.4, SK].

1885. Galinsoga ciliata (Raf.) S.F. Blake - Miskolc-Bükkszentlászló: Galya-tető nyugati pereme, település szélén [7990.1, NT, SK, MCs].

1899. Achillea nobilis L. - Erdőbénye: Petrás-oldal [7794.3, MCs]; Érsekvadkert: Göröc [7981.3, 2011, MÁ]; Ludányhalászi: Agyagos-hegy [7883.3, 2011, MÁ].

1903. Achillea setacea Waldst. et Kit. - Hatvan: Kisgombosi fás legelő [8284.3, 2010, MÁ].

1905. Achillea pannonica Scheele - Lácacséke: Szilvás-homok [7697.2, MCs]; Sajókaza: Szárhegy [7789.2, 2008, MÁ].

1907. Achillea millefolium L. s. str. - Gömörszőlős: Kis- és Nagy-kenderföld melletti lápréteken [herb, 7688.2, MCs].

1914. Tanacetum corymbosum (L.) Sch. Bip. - Egerbakta: Rábca-hegy, mészkerülő tölgyesben [8087.4, NT, SK, MCs]; Zádorfalva: Ragyás-szőlő [7688.2, 2008, MÁ].

1918. Leucanthemum vulgare Lam. s. str. - Szászfa: Janka-patak völgye [7591.1, 7591.2, MCs]. 
1919. Leucanthemum ircutianum DC. - Tornaszentjakab: Kerek-domb, erdőszélen [7491.3, MCs].

1933. Petasites hybridus (L.) G. Gaertn., B. Mey. et Schreb. - Jákfalva: a Szuha-menti kis hídnál [7689.3, 2009, MÁ].

1941. Tephroseris integrifolia (L.) Holub - Abaújkér: Gyűr-völgy [7793.1, MCs].

1946. Senecio vernalis Waldst. et Kit. - Sajóecseg: vasútállomás [7890.2, MCs]; Tornanádaska: vasútállomás [7490.2, MCs].

1948. Senecio erucifolius L. - Gömörszőlős: Szőlő-hegy [7688.2, 2006, MÁ].

1951. Senecio erraticus Bertol. - Monok: Oláh-völgy [7792.4, MCs].

1962. Carlina vulgaris L. - Tárnokréti: Tehénlegelőn néhány szál, a magasabb fekvésű részeken [8269.4, HGy].

1964. Xeranthemum annuum L. - Bátonyterenye-Szúpatak: Kányás-tető és Szőlő-hegy [7984.4, 2011, MÁ]; Szalmatercs: Cseres-oldal [7883.4, 2011, MÁ].

1967. Arctium tomentosum Mill. - [7591.1, MCs]; [8887.1, HGy].

1978. Carduus collinus Waldst. et Kit. - Meszes: Jóna-hegy [7590.2, 7590.4, MCs]; Rakaca: a belterülettől Ny-ra, útszéli sziklaletörésen [7591.1, MCs].

1979. Cirsium vulgare (Savi) Ten. - Hatvan: Kisgombosi fás legelő [8284.3, 2010, MÁ].

1984. Cirsium brachycephalum Jur. - Sarud: a település nyugati szélén, taposott, marhával legeltetett területen [8489.2, SK].

1993. Serratula tinctoria L. - Monok: Hosszú-völgy északi részén [7792.4, MCs]; Szolnok: Zagyva ártér mélyebb fekvésű medencéiben [8787.3, HGy].

2000. Centaurea indurata Janka - Alsószuha: Felső-Rónya és Dövény: Gödör-köz-dűlő [7689.1, 2009, MÁ].

2003. Centaurea cyanus L. - Rakacaszend: a falu körüli szántókon [7591.1, MCs].

2008.2 Centaurea scabiosa L. subsp. spinulosa (Rochel) Arcang. - Szuhafő: Ragyás-szőlő [7688.2, 2009, MÁ].

2008.3 Centaurea scabiosa L. subsp. scabiosa - Zemplénagárd: a temető melletti dombon [7698.1, MCs].

2010. Centaurea stoebe L. - Erdőbénye: Petrás-oldal [7794.3, MCs]; Lácacséke: Szilvás-homok [7697.2, MCs]; Meszes: Jóna-hegy [7590.2, 7590.4, MCs]; Rakaca: a belterülettől Ny-ra, útszéli sziklaletörésen [7591.1, MCs]; Szolnok: Száraz gyepek, útszélek [8787.3, 8887.1, HGy].

2016. Hypochoeris maculata L. - Szuhafő: Ragyás-szőlő [7688.2, 2009, MÁ].

2017. Hypochoeris radicata L. - Zemplénagárd: gátoldal [7698.1, MCs].

2021. Leontodon hispidus L. - [7696.3, MCs].

2028. Scorzonera austriaca Willd. - Monok: Pipiske [herb, 7892.2, MCs].

2036. Sonchus oleraceus L. - Hatvan: Kisgombosi fás legelő [8284.3, 2010, MÁ].

2037. Sonchus palustris L. - Jákfalva: a Szuha menti kis hídnál [7689.3, 2009, MÁ].

2038. Sonchus arvensis L. - [8787.3, HGy].

2042. Lactuca saligna L. - Putnok: Külső bányatelep, szénbányászati meddőhányón [7788.2, MCs]; Sárospatak: vasútállomás [7695.3, MCs].

2048. Taraxacum serotinum (Waldst. et Kit.) Poir. - Felsődobsza: Hernád-magaspart [7792.3, MCs]; Megyaszó: Csorgó-legelő [7892.1, MCs].

2056. Crepis setosa Haller - [7891.2, MCs]; [8887.1, HGy].

2059. Crepis pulchra L. - Szolnok: Tiszavirág híd tövében, jobb parton, Tisza-parti kövezés között [8887.1, HGy].

2061. Crepis tectorum L. - [herb, 7789.2, MCs]; [herb, 2016, 7893.1, MCs].

2073. Hieracium bauhinii Schult. ex Besser - Erdőbénye: Petrás-oldal [7794.3, MCs].

2145. Hemerocallis lilio-asphodelus L. - Ják: Jáki-Alsó-erdő, Hidegkúti-patak mentén [1980

k.] és Kisunyom: a Koci-dombon [1990-es évek, 8865.4, LZ].

2171. Allium vineale L. - Szolnok: Zagyva ártér, Cirsium arvense által uralt gyepben [8787.3, HGy]. 
MoLNÁR et al. (2018): Pótlások Magyarország edényes növényfajainak elterjedési atlaszához VI.

2172.1 Allium sphaerocephalon L. subsp. sphaerocephalon - Sajóecseg: a főút felől a faluba vezető műút mentén [herb, 7890.2, MCs].

2174. Allium scorodoprasum L. - Hatvan: Kisgombosi fás legelő [8284.3, 2010, MÁ].

2175. Allium rotundum L. - Szalmatercs: Cseres-oldal [7883.4, 2011, MÁ].

2190. Allium flavum L. - Hatvan: Kisgombosi fás legelő [8284.3, 2010, MÁ].

2193. Maianthemum bifolium (L.) F.W. Schmidt - Alsószuha: Bakóc-völgy [7689.1, 2009, MÁ]; Felsőnyárád: Kővágó [7689.4, 2009, MÁ].

2195. Polygonatum latifolium (Jacq.) Desf. - [7893.1, MCs].

2196. Polygonatum odoratum (Mill.) Druce - [7893.1, MCs].

2198. Asparagus officinalis L. - Szolnok: Vízelvezető árok melletti „ligetben”, nemesített nőszirmok mellett [8887.1, HGy].

2209. Potamogeton crispus L. - Vadna: Sziget, kavicsbányatóban [7789.1, MCs].

2222. Gagea pratensis (Pers.) Dumort. - Megyaszó: Hosszú-hegy és Monok: Csörgő-domb, Lete-erdő, Halom alja és Ingvár [7892.2, MCs]

2223. Gagea lutea (L.) Ker Gawl. - Hatvan: Kisgombosi fás legelő [8284.3, 2010, MÁ].

2225. Gagea pusilla (F.W. Schmidt) Schult. et Schult. f. - Legyesbénye: Majos, Megyaszó: Hosszú-hegy és Monok: Halom alja, Pipiske és Kaptár-hegy [herb, 7892.2, MCs]; Monok: Zsebrik alja, Borjú-völgy felé [7792.4, MCs].

2233. Fritillaria meleagris L. - Szászfa: Nagy-rét [7591.1, 2014-2017, HS, HK, MCs]; Szászfa: Janka-patak völgye [7591.2, 2014-2017, HS, HK, MCs].

2235. Lilium martagon L. - Ivánc: a falutól É-ra, a Sigray-erdőben [2000-es évek, 9064.4, LZ]; Ják: a Jáki-Alsó-erdő Ny-i felében, a Hidegkúti-patak fölötti domboldalon [2000-es évek, 8865.4, LZ]; Monok: Hideg-völgy [7893.1, MCs]; Sopronkövesd: a Széchenyi-kápolna melletti erdősült parkban szórványos [2014, 8466.3, BL].

2251. Iris pseudacorus L. - [7794.3, MCs].

2254. Iris sibirica L. - Szászfa: Nagy-rét, hozzávetőlegesen két tucat polikormon [7591.1, 7591.2, 2014-2017, HS, HK, MCs].

2266. Gladiolus imbricatus L. - Nárai: Zsidu-rét, egy tucat virágzó tő [2016, 8765.3, VL].

2275. Juncus bufonius L. s. str. - Erdőbénye: Petrás-oldal [7794.3, MCs].

2277. Juncus compressus Jacq. - Komjáti: belterületen, útszélen [herb, 7490.4, MCs]; Sajóvelezd: Ilona-forrás előtti parkoló [7788.2, MCs].

2289. Luzula campestris (L.) DC. s. str. - Abaújkér: Gyűr-tető [7793.1, MCs]; Rakaca: Szendioldal [7591.1, MCs].

2293. Commelina communis L. - Szolnok: Járdaszegélyekben városszerte előfordul [8887.1, HGy].

2297. Festuca arundinacea Schreb. - Ludányhalászi: Király-hegy [7883.3, 2011, MÁ].

2298. Festuca pratensis Huds. - [7591.1, MCs].

2301. Festuca rubra L. - Abaújalpár: Bánya-hegy [7693.3, MCs]; Felsőkelecsény: Felső-rét [7689.2, MCs]; Szuhogy: Csátés [7690.1, MCs].

2310. Festuca rupicola Heuff. - Zádorfalva: Iván-tető [7688.2, 2006, MÁ].

2315. Festuca valesiaca Schleich. ex Gaudin - Hatvan: Kisgombosi fás legelő [8284.3, 2010,

MÁ]; Sajókaza: Szár-hegy [7789.2, 2008, MÁ].

2317. Lolium perenne L. - [8787.3, HGy].

2318. Lolium multiflorum Lam. - Hatvan: Kisgombosi fás legelő [8284.3, 2010, MÁ].

2322. Vulpia myuros (L.) C.C. Gmel. - Szolnok: vasútállomás, peronon [8887.1, MCs].

2324. Poa bulbosa L. - [9084.3, MCs].

2325. Poa badensis Haenke ex Willd. - Hidvégardó: Szent János-kő [herb, 7491.3, MCs].

2327. Poa compressa L. - [7698.1, 7788.2, 7894.1, MCs].

2333. Poa nemoralis L. - Alsószuha: Bakóc-völgy [7689.1, 2009, MÁ].

2334. Poa palustris L. - Szegilong: Örvény [7794.3, MCs]; Zubogy: Meskó-rét [7689.1, 2006, MÁ]. 2337. Poa angustifolia L. - [8887.1, HGy]. 
2341. Sclerochloa dura (L.) Beauv. - Bodrogkisfalud: vasútállomás [7894.1, MCs]; Szolnok: száraz gyepek, töltéskoronák [8887.1, HGy].

2345. Cynosurus cristatus L. - Abaújalpár: Bánya-hegy [7693.3, MCs].

2346. Catabrosa aquatica (L.) P. Beauv. - Szuhafö: Szarvas domb alatt [7588.4, 2006, MÁ].

2347. Apera spica-venti (L.) Beauv. - [7490.4, 7788.1, 7788.2, MCs].

2349. Briza media L. - Rakaca: Szendi-oldal [7591.1, MCs]; Szászfa: Janka-patak völgye [7591.2, MCs].

2356. Melica transsilvanica Schur - Lácacséke: Szilvás-homok [7697.2, MCs]; Meszes: Jónahegy [7590.4, MCs]; Putnok: Külső bányatelep, szénbányászati meddőhányón [7788.2, MCs].

2359. Melica nutans L. - Hidvégardó: Szent János-kő [7491.3, MCs].

2370. Bromus hordeaceus L. - [7789.2, MCs].

2375. Bromus arvensis L. - Hatvan: Kisgombosi fás legelő [8284.3, 2010, MÁ].

2376. Bromus japonicus Thunb. - Bódvalenke, Hidvégardó és Komjáti: útszéleken sokfelé [7490.4, MCs]; Erdőbénye: Petrás-oldal és Olaszliszka: Meszesmajor [7794.3, MCs]; Gömörszőlős: belterület [7688.2, MCs]; Kazincbarcika: Kazincbarcika alsó vasúti megállóhely [7789.2, MCs]; Kelemér: Szilas alja [7688.4, MCs]; Rakaca: a belterülettől Ny-ra, útszéli sziklaletörésen [7591.1, MCs]; Sajóecseg: vasútállomás [7890.2, MCs]; Sóstófalva: Sóstófalvi elágazás buszmegálló [7891.2, MCs]; Tornanádaska: vasúti sínek mentén [7490.2, MCs]; Vadna: Sziget és Töltés alja [7789.1, MCs].

2378. Bromus commutatus Schrad. - Gömörszőlős: Egerdő-tető, parlagon [7688.2, MCs].

2379. Bromus inermis Leyss. - [8787.3, HGy].

2384. Bromus benekenii (Lange) Trimen - Sajónémeti: Rátos-oldal [7788.1, MCs]; Tornaszentjakab: Kerek-domb [7491.3, MCs].

2388. Bromus tectorum L. - [7490.2, 7789.2, MCs].

2390. Brachypodium pinnatum (L.) P. Beauv. - Ludányhalászi: Agyagos-hegy és Király-hegy [7883.3, 2011, MÁ].

2394. Elymus elongatus (Host) Runemark cv. Szarvasi-1 - Nemesgulács: ÉK-re, kaszálórét út menti szélén gyakori [herb, 2015, 9170.4, BL].

2396. Elymus hispidus (Opiz) Melderis - Sajókaza: Szár-hegy [7789.2, 2008, MÁ].

2397. Agropyron cristatum (L.) Gaertn. - Zemplénagárd: gát tetején, a Vesszős-dűlő területén [7698.1, MCs].

2410. Hordeum hystrix Roth - Szolnok: száraz gyepekben [8787.3, HGy].

2412. Hordelymus europaeus (L.) Less. ex Harz - Miskolc-Bükkszentlászló: Szederbokor, gyertyános-tölgyesben [herb, 7990.1, NT, SK, MCs].

2424. Arrhenatherum elatius (L.) P. Beauv. ex J. Presl et C. Presl. - [8787.3, HGy].

2441. Anthoxanthum odoratum L. - Abaújkér: Gyür-tető [7793.1, MCs]; Rakaca: Szendi-oldal és Szászfa: Janka-patak völgye [7591.1, MCs]; Szászfa: Janka-patak völgye [7591.2, MCs].

2443. Holcus lanatus L. - Gömörszőlős: Kis-kenderföld melletti lápréten [7688.2, MCs]; Tornanádaska: Töltés felett [7490.2, MCs].

2446. Agrostis capillaris L. - Abaújalpár: Bánya-hegy [7693.3, MCs]; Erdőbénye: Petrás-oldal [7794.3, MCs].

2447. Agrostis stolonifera L. s. str. - [7698.1, MCs].

2448. Agrostis gigantea Roth - Tornaszentjakab: Sas-pataki földek, magassásréten [7491.3, MCs]. 2460. Phleum phleoides (L.) H. Karst. - Hatvan: Kisgombosi fás legelő [8284.3, 2010, MÁ].

2463. Alopecurus pratensis L. - [7591.2, 2014-2017, HS, HK, MCs].

2469. Phalaris arundinacea L. - [7491.3, MCs].

2479. Stipa pulcherrima K. Koch - Meszes: Jóna-hegy [7590.2, MCs].

2483. Danthonia decumbens (L.) DC. - Alsószuha: Bakóc-völgy és Rónyapuszta között [7689.1, 2009, MÁ].

2488. Eragrostis minor Host - [7490.2, 7695.3, 7795.1, 7888.2, MCs]. 
MoLNÁR et al. (2018): Pótlások Magyarország edényes növényfajainak elterjedési atlaszához VI.

2490. Eragrostis pilosa (L.) Beauv. - Bodrogolaszi: vasútállomás [7795.1, MCs]; Vadna: vasútállomás [7789.1, MCs].

2498. Cynodon dactylon (L.) Pers. - [7591.1, MCs].

2499. Tragus racemosus (L.) All. - Bodrogkisfalud: vasútállomás [7894.1, MCs]; Miskolc: a repülőtér melletti bevásárlóközpontok díszkövezetében [7890.4, MCs]; Sárospatak: vasútállomás [7695.3, MCs].

2504. Panicum capillare L. s. str. - Bodrogkisfalud: vasútállomás [herb, 7894.1, MCs].

2510. Digitaria sanguinalis (L.) Scop. - [8887.1, HGy].

2517. Cenchrus incertus M.A. Curtis - Debrecen: Múzeum u. és Hatvan u. közötti sikátorban $[8495.4, \mathrm{SK}]$.

2518. Sorghum halepense (L.) Pers. - Maglóca: műút mente [8369.2, HGy]; Szolnok: műutak mentén [8887.1, HGy].

2593.2 Carex praecox Schreb. subsp. intermedia (Čelak.) W. Schultze-Motel - Erdőbénye: Petrás-oldal, bokorerdőben [7794.3, MCs].

2601. Carex vulpina L. s. str. - Szalmatercs: Cseres-oldal [7883.4, 2011, MÁ]; Tállya: Csátó [7793.3, MCs].

2602. Carex otrubae Podp. - Bátonyterenye-Szúpatak: Kányás-tető és Szőlő-hegy [7984.4, 2011, MÁ].

2608. Carex stenophylla Wahlenb. - Hatvan: Kisgombosi fás legelő [8284.3, 2010, MÁ].

2611. Carex acuta L. - Tállya: Csátó [7793.3, MCs].

2618. Carex hirta L. - [7697.2, MCs].

2621. Carex flacca Schreb. - Abaújszántó: Mező-fenék [7792.2, MCs].

2623. Carex digitata L. - Monok: Pap erdeje, Lány-kő [7893.1, MCs].

2626. Carex tomentosa L. - Felsődobsza: Hernád-magaspart [7792.3, MCs]; Szászfa: Jankapatak völgye [7591.2, MCs].

2636. Carex pallescens L. - Rakaca: Szendi-oldal [7591.1, MCs]; Szalmatercs: Cseres-oldal [7883.4, 2011, MÁ]; Szászfa: Janka-patak völgye [7591.2, MCs].

2637. Carex supina Wahlenb. - Abaújkér: Gyűr-tető [7793.1, MCs]; Monok: Pipiske [7892.2, MCs].

2653. Carex viridula Michx. - Fehértó: Tó melletti lápréten. Fehértó-Győrsövényház közötti kavicsos úttól É-ra [8370.1, HGy].

2656. Carex distans L. - Tornanádaska: Töltés felett [herb, 7490.2, MCs].

2659. Epipactis microphylla (Ehrh.) Sw. - Tornaszentjakab: Kerek-domb, néhány tő [7491.3, MCs].

2673. Epipactis helleborine (L.) Crantz - Szombathely: Árpád út, Vasi Skanzen, kb. 40 éve faiskolai célú Quercus palustris-csemetésből felnőtt faültetvényben gyakori [2011, 8765.4, BL]. 2675. Cephalanthera rubra (L.) Fritsch - Tornaszentjakab: Kerek-domb, néhány tő [7491.3, MCs].

Helyesbítés

1319. Heracleum sosnowskyi Manden. - Keszthely: a H. mantegazzianum helyett mindkét negyedkvadrátban valójában ez! [1990-es évek második fele, 9269.1, 9269.3, BL, DI = Dancza István]. - Az eredeti adatok Almádi László határozása nyomán kerültek be a Bódis Judit és Szalóky Ildikó által térképezett kvadrátok flóralistájába. Almádi László kutatásainak idején a H. sosnowskyi-nak még nemigen volt közölt hazai adata, ezért gondolhatta, hogy Keszthelyen is a H. mantegazzianum él. Az agráregyetemen az előbbi fajjal folytak termesztési kísérletek, s az vadulhatott ki. A helyesbítés a flóralisták szerzőinek egyetértésével történik. 


\section{Köszönetnyilvánítás}

Sokirányú segítségükért Molnár Csaba köszönettel tartozik Barina Zoltánnak, Farkas Tündének, Juhász Melindának, Schmidt Dávidnak, Szmorad Ferencnek és Virók Viktornak, továbbá Horváth Soma Fadel Nadinnak, valamint adataik rendelkezésre bocsátásáért Süveges Kristóf Gulyás Gergelynek, Balogh Lajos pedig Lendvai Zoltánnak, Takács Bélának és Varga Lászlónak. Köszönjük a lektorok - Bartha Dénes, Tiborcz Viktor és Schmidt Dávid - javító szándékú megjegyzéseit.

\section{Irodalom}

Bartha D., Király G., Schmidt D., Tiborcz V., Barina Z., Csiky J., Jakab G., LeSku B., Schmotzer A., Vidéki R., Vojtкó A. \& ZóLYomi Sz. (szerk.) (2015): Magyarország edényes növényfajainak elterjedési atlasza. Nyugat-magyarországi Egyetem Kiadó, Sopron.

CSIKY J., BARÁth K., Bocz V., Deme J., FülÖP Zs., Kovács D., NAGy K., TAMÁsi B. \& CsikYNÉ RadNAi É. (2017): Pótlások Magyarország edényes növényfajainak elterjedési atlaszához V. - Kitaibelia 22 (2): 383-403.

KEVEY B. (2017): Pótlások Magyarország edényes növényfajainak elterjedési atlaszához IV. - Kitaibelia 22 (2): 358-382.

KIRÁLY G. (szerk.) (2009): Új Magyar Füvészkönyv. Magyarország hajtásos növényei. Határozókulcsok. Aggteleki Nemzeti Park Igazgatósága, Jósvafő.

Molnár Cs., Haszonits Gy., Malatinszky Á., KovÁcs G. K., Kovács G., Nagy T., MolnÁr V. A. \& TAKács A. (2017): Pótlások Magyarország edényes növényfajainak elterjedési atlaszához III. - Kitaibelia 22 (1): 122-146.

Molnár Cs., Lengyel A., Molnár V. A., NAGY T., CsáBI M. \& TAKÁCS A. (2016): Pótlások Magyarország edényes növényfajainak elterjedési atlaszához II. - Kitaibelia 21 (2): 227-252.

NikLFELD H. (1971): Bericht über die Kartierung der Flora Mitteleuropas. - Taxon 20 (4): 545-571.

TAKÁcs A., NAgy T., SRAmKó G., Lovas-Kiss Á., Süveges K., LuKÁcs B. A., FEKETE R., LöKi V., Malatinszky Á., E. VojtKó A., Koscsó J., Pfliegler W. P., NóTÁRI K. \& MolnÁR V. A. (2016): Pótlások a Magyarország edényes növényfajainak elterjedési atlaszához I. - Kitaibelia 21 (1): 101-115.

Beérkezett / received: 2018. 03. 07. • Elfogadva / accepted: 2018. 04. 20. 